\title{
Optimization of Injection Moulding Process Parameters in the Moulding of High Density Polyethylene (HDPE)
}

\author{
OSARENMWINDA, JO; *OLODU, DD
}

\author{
Department of Production Engineering, Faculty of Engineering, University Of Benin, Benin City, Nigeria \\ E-Mail:joosarenmwinda@uniben.edu'Tel: +234-802-371-8684, "Email: dickson.olodu@eng.uniben.edu.Tel: +234-806-532-5363
}

\begin{abstract}
In this study, optimal injection moulding conditions for minimum shrinkage during moulding of High Density Polyethylene (HDPE) were obtained by Taguchi method. The result showed that melting temperature of $190^{\circ} \mathrm{C}$, injection pressure of $55 \mathrm{MPa}$, refilling pressure of $85 \mathrm{MPa}$ and cooling time of 11 seconds gave minimum shrinkage for High Density Polyethylene. Cooling time was found to be the factor with most significant effect on the shrinkage of High Density Polyethylene followed by refilling pressure. Injection pressure was found to be the least effective factor.
\end{abstract}

DOI: https://dx.doi.org/10.4314/jasem.v22i2.8

Copyright: Copyright (C) 2018 Osarenwinda and Olodu. This is an open access article distributed under the Creative Commons Attribution License (CCL), which permits unrestricted use, distribution, and reproduction in any medium, provided the original work is properly cited

Dates: First received 14 December 2017; Received in revised form 15 January 2018; Accepted 10 February 2018

Keywords: High Density Polyethylene (HDPE), Injection Moulding, Process Parameters, Taguchi method.

Injection moulding is a very complex process and its process variable like barrel (melt) temperature, injection pressure, the material flow rate, mould temperature and flow pattern usually interact between themselves and with the polymer properties to influence the solid properties of the moulded products (Osarenmwinda and Olodu, 2015). Injection moulding is a manufacturing process for producing parts by injecting material into a mould (Rosato et al., 2000). Injection moulding can be performed with a host of materials, including metals, glasses, elastomers, confections, and most commonly thermoplastic and thermosetting polymers (Pötsch and Michaeli, 1995). Material for the part is fed into a heated barrel, mixed, and forced into a mould cavity where it cools and hardens to the configuration of the cavity. After a product is designed, usually by an industrial designer or an engineer, moulds are made by a mould maker (or toolmaker) from metal, usually either steel or aluminum, and precisionmachined to form the features of the desired part. Injection moulding is widely used for manufacturing a variety of parts, from the smallest components to entire body panels of cars (Brydson, 1995). Injection moulded parts must be very carefully designed to facilitate the moulding process. The material used for the part, the desired shape and features of the part, the material of the mould and the properties of the moulding machine must all be taken into account. The versatility of injection moulding is facilitated by the breadth of design considerations and possibilities.
Shrinkage is one of the most important reasons that cause dimensional changes in the part, and it can be minimized by setting optimal process parameters on injection moulding machine (James Anderson et al., 2014). Huang and Tai [2001] studied the effect of five input parameters on surface quality of thin moulded parts. The input parameters were mould temperature, melting temperature, packing pressure, packing time and injection time. Altan (2010) utilized Taguchi method to optimize shrinkage of plastic, Polypropylene (PP) and Polystyrene (PS), injection moulding parts. He also applied neural network to model the process and was able to achieve $0.937 \%$ and $1.224 \%$ shrinkage in PP and PS, respectively. Neeraj Singh et al (2015) showed how cycle time reduction can be done on injection moulding machine for DVD manufacturing by optimizing the parameter of injection moulding machine. He showed that by optimizing the effective distance travel and speed of mould, the DVD moulding cycle time can be reduced. He concluded that cooling time and hold time are also effective parameters to reduce cycle time (Kothari, 2016).

Alireza Akbarzadeh and Mohammad Sadeghi (2011) studied the relationship between input and output of the process using ANOVA. They considered four input parameters such as melting temperature, packing pressure, packing time and injection time and found that the packing pressure is the most effective, while injection pressure is the least 
important parameter for Polypropylene (PP). Vaatainen et al., (2016) investigated the effect of the injection moulding parameters on the visual quality of mouldings using the Taguchi method. They focused on the shrinkage with three more quality characteristics: weight, weld lines and sink marks. They were able to optimize many quality characteristics with very few experiments, which could lead to cost saving. Mohd. Muktar Alam and Deepak Kumar (2013) in their paper determined optimal injection moulding condition for minimum shrinkage by the DOE technique of Taguchi methods. Packing pressure was found to be the most effective factor for Polypropylene (PP) followed by packing time, injection pressure and melt temperature. Gang et al (2011) in their study presented an innovative neural network-based quality prediction system for a plastic injection moulding process.

The particle swarm optimization algorithm (PSO) was analyzed and an adaptive parameter-adjusting PSO algorithm based on velocity information (APSO-VI) was put forward. Experimental results show that APSO-VINN can better predict the product quality (volume shrinkage and weight) and can likely be used for various practical applications. From the literature review, it can be concluded that, in order to minimize such shrinkage defects in plastic injection moulding, design of experiment by Taguchi method can be applied and is considered suitable by many researchers. In experimental design, there are many variable factors that affect the functional characteristics of the product. Design parameter values that minimize the effect of noise factors on the product's quality are to be determined. In order to find optimum levels, fractional factorial designs using orthogonal arrays are used. In this way, an optimal set of process conditions can be obtained from very few experiments. This study is to determine the optimal injection moulding process parameters in the moulding of High Density Polyethylene in order to reduce the shrinkage defect to the barest minimum.

\section{MATERIALS AND METHODS}

Materials: The input parameters selected are melting temperature, injection pressure, refilling pressure and cooling time. Shrinkage is selected as output. The material selected is HDPE-16MA-400. Properties of HDPE are shown in Table 1. 16MA-400 is an injection moulding grade film for High Density Polyethylene (HDPE) produced by high pressure tubular process. The high melt flow index makes it ideal for moulding of very thin, intricate and large items having adequate mechanical properties. This grade is also an ideal choice for making master batches with higher loading.

Table 1: Properties of High Density Polyethylene (HDPE)

\begin{tabular}{llc}
\hline Property & Unit & Typical Value \\
\hline Density $\left(24^{\circ} \mathrm{C}\right)$ & $\mathrm{g} / \mathrm{cm}^{3}$ & 0.918 \\
Melt Flow Index & $\mathrm{g} / 10$ minutes & 30 \\
Tensile Strength at Yield & $\mathrm{MPa}$ & 10 \\
Elongation at Yield & $\%$ & 40 \\
Flexural Modulus & $\mathrm{MPa}$ & 140 \\
\hline
\end{tabular}

The following methods were used in this study:

Injection Moulding: Process: The part was injection moulded using a 100-ton injection moulding machine (Polyplast) (Osarenmwinda and Olodu, 2015)

Taguchi Technique: Taguchi technique is recommended to use orthogonal array experiments. It is used to optimize the performance characteristics within the combination of design parameters (Taguchi, 1990). In the product/process design of Taguchi, there are basically three steps involved: (i) System Design: Selection of a system for a given objective function. (ii) Parameter Design: To find the optimum combinations of the process conditions for improving performance characteristics. (iii)Tolerance Design: Determination of tolerance around each parameter level.

Taguchi method uses signal-to-noise $(\mathrm{S} / \mathrm{N})$ ratio which reflects both the average and the variation of the quality characteristics. It is a measure of performance aimed at developing products and processes insensitive to noise factors.

Types of S/N ratio:

(i) Larger-the-better: $\frac{S}{N}=-10 \log _{10}\left(\frac{1}{n} \Sigma \frac{1}{y_{i}^{2}}\right)$, where $\mathrm{i}=1$ to $\mathrm{n}, \mathrm{n}=$ Number of replications applied to the problems where maximization of quality characteristics of interest is needed.

(ii) Smaller-the-better: $\frac{S}{N}=-10 \log _{10}\left(\frac{1}{n} \Sigma \frac{1}{y_{i}^{2}}\right)$. It is used where minimization of the characteristics is intended.

(iii) Nominal-the-best: $\frac{S}{N}=-10 \log _{10}\left[\frac{\mu^{2}}{\sigma^{2}}\right]$ where $\mu$ $=$ mean, $\sigma=$ standard deviation. It is used where one tries to minimize the mean squared error around a specific target value. Adjusting the mean to the target by any method renders the problem to a constrained optimization problem.

Experimental Design: Three levels of processing parameters and L9 orthogonal array were selected. The process parameters and levels are shown in Table 2 and L9 orthogonal array is shown in Table 3. 
Shrinkage measurement: It is the difference between the size of mould cavity and size of finished part divided by size of the mould. $S=\frac{D_{m}-D_{p}}{D_{m}} X 100$. Here, $D_{m}$ is mould dimension, $D_{P}$ is part dimension and $\mathrm{S}$ is the shrinkage.

Table 2: The Process Parameters and Levels

\begin{tabular}{|c|c|c|c|c|c|c|}
\hline $\begin{array}{l}\text { Serial } \\
\text { Number }\end{array}$ & \multicolumn{3}{|c|}{ Factors } & $\begin{array}{c}\text { Level } \\
1\end{array}$ & $\begin{array}{c}\text { Level } \\
2\end{array}$ & $\begin{array}{l}\text { Level } \\
3\end{array}$ \\
\hline 1 & \multicolumn{3}{|c|}{$\begin{array}{l}\text { Melting Temperature, } \\
\mathrm{A}\left({ }^{\circ} \mathrm{C}\right)\end{array}$} & 190 & 200 & 210 \\
\hline 2 & \multicolumn{3}{|c|}{$\begin{array}{l}\text { Injection Pressure, B } \\
(\mathrm{MPa})\end{array}$} & 55 & 60 & 70 \\
\hline 3 & \multicolumn{3}{|c|}{$\begin{array}{l}\text { Refilling Pressure, C } \\
\text { (MPa) }\end{array}$} & 75 & 80 & 85 \\
\hline 4 & \multicolumn{3}{|c|}{ Cooling Time, D } & 7 & 9 & 11 \\
\hline \multicolumn{7}{|c|}{ Table 3: The L9 Orthogonal Array } \\
\hline \multicolumn{2}{|c|}{ Serial Number } & A & B & & $\mathbf{C}$ & D \\
\hline \multicolumn{2}{|c|}{1} & 1 & 1 & & 1 & 1 \\
\hline \multicolumn{2}{|l|}{2} & 1 & 2 & & 2 & 2 \\
\hline \multicolumn{2}{|l|}{3} & 1 & 3 & & 3 & 3 \\
\hline \multicolumn{2}{|l|}{4} & 2 & 1 & & 2 & 3 \\
\hline \multicolumn{2}{|l|}{5} & 2 & 2 & & 3 & 1 \\
\hline \multicolumn{2}{|l|}{6} & 2 & 3 & & 1 & 2 \\
\hline \multicolumn{2}{|l|}{7} & 3 & 1 & & 3 & 2 \\
\hline \multicolumn{2}{|l|}{8} & 3 & 2 & & 1 & 3 \\
\hline \multicolumn{2}{|l|}{9} & 3 & 3 & & 2 & 1 \\
\hline
\end{tabular}

\section{RESULTS AND DISCUSSION}

Experimental result for High Density Polyethylene (HDPE) is shown in Table 4. In this study lower value of shrinkage behavior is expected to be obtained. Thus, for $\mathrm{S} / \mathrm{N}$ ratio characteristic the lowerthe-better is applied in the analysis of experimental result, which is shown in Table 4.

Table 4: Shrinkage Value for High Density Polyethylene. (HDPE)

\begin{tabular}{lllll}
\hline $\begin{array}{l}\text { Melting } \\
\text { Temperature } \\
\left({ }^{\circ} \mathbf{C}\right)\end{array}$ & $\begin{array}{l}\text { Injection } \\
\text { Pressure } \\
(\mathbf{M P a})\end{array}$ & $\begin{array}{l}\text { Refilling } \\
\text { Pressure } \\
(\mathbf{P M a})\end{array}$ & $\begin{array}{l}\text { Cooling } \\
\text { Time }(\mathbf{s})\end{array}$ & $\begin{array}{l}\text { Shrinkage } \\
\text { Percentage } \\
(\%) \text { HDPE }\end{array}$ \\
\hline 190 & 55 & 75 & 7 & 1.575 \\
190 & 60 & 80 & 9 & 1.500 \\
190 & 70 & 85 & 11 & 1.25 \\
200 & 55 & 80 & 11 & 1.437 \\
200 & 60 & 85 & 7 & 1.50 \\
200 & 70 & 75 & 9 & 1.625 \\
210 & 55 & 85 & 9 & 1.375 \\
210 & 60 & 75 & 11 & 1.40 \\
210 & 70 & 80 & 7 & 1.78 \\
\hline
\end{tabular}

Table 5: The Response Table for S/N ratio for High Density

\begin{tabular}{|c|c|c|c|c|}
\hline \multicolumn{5}{|c|}{ hylene (HDPE) } \\
\hline $\begin{array}{l}\text { Serial } \\
\text { Number }\end{array}$ & $\begin{array}{l}\text { Melting } \\
\text { Temperature, } \\
\text { A }\left({ }^{\circ} \mathbf{C}\right)\end{array}$ & $\begin{array}{l}\text { Injection } \\
\text { Pressure } \\
\text { B, (MPa) }\end{array}$ & $\begin{array}{l}\text { Kefilling } \\
\text { Pressure, } \\
\text { C (MPa) }\end{array}$ & $\begin{array}{l}\text { Cooling } \\
\text { Time, D } \\
\text { (s) }\end{array}$ \\
\hline Level 1 & -3.135 & -3.287 & -3.695 & -4.159 \\
\hline Level 2 & -3.629 & -3.322 & -3.893 & -3.502 \\
\hline Level 3 & -3.566 & -3.721 & -2.742 & -2.670 \\
\hline Delta & 0.494 & 0.434 & 1.151 & 1.489 \\
\hline Rank & 3 & 4 & 2 & 1 \\
\hline
\end{tabular}

The response Table of the $\mathrm{S} / \mathrm{N}$ ratio is shown in Table 5. The best set of combination parameter can be determined by selecting the level with highest value for each factor. The optimal process parameter combination for High Density Polyethylene (HDPE) is $\mathrm{A} 1, \mathrm{~B} 1, \mathrm{C} 3$, and D3. The Delta value given in Table 5 shows the factor that is most significant for shrinkage of High Density Polyethylene (HDPE) moulding. Cooling time with a Delta value 1.489 was found to be the factor with most significant effect on the shrinkage of High Density Polyethylene (HDPE) followed by refilling pressure with Delta value of 1.151 (Table 5). Injection pressure was found to be the least effective factor with Delta value of 0.434 . $\mathrm{S} / \mathrm{N}$ ratio response diagram was drawn and is shown in Figure 1. The highest $\mathrm{S} / \mathrm{N}$ ratio for each factor gave the optimal process condition which corresponds to melting temperature of $190^{\circ} \mathrm{C}$, injection pressure of $70 \mathrm{MPa}$, refilling pressure of 85 $\mathrm{MPa}$ and cooling time of 11 seconds (Figure 1).

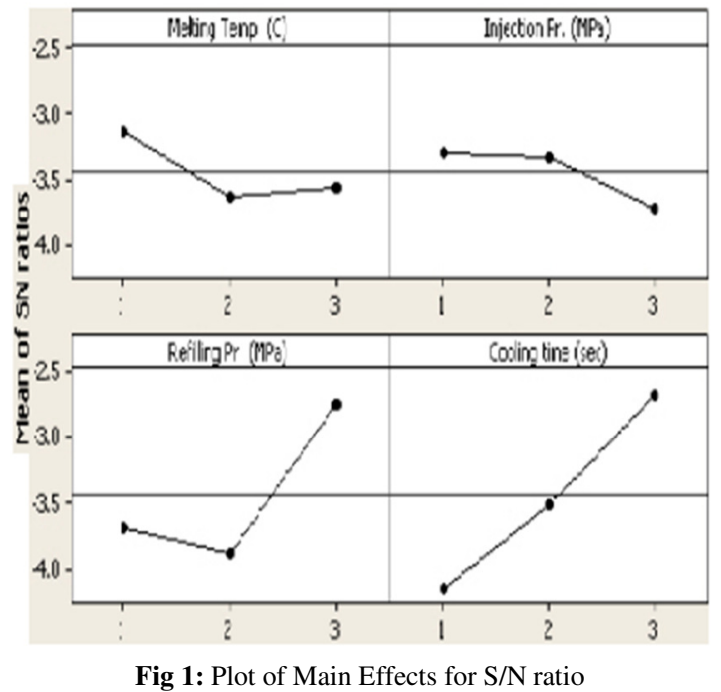

Conclusion: Taguchi method was used to determine the optimum combinations of the process conditions for shrinkage of HDPE material. The result showed that melting temperature of $190^{\circ} \mathrm{C}$, injection pressure of $70 \mathrm{MPa}$, refilling pressure of $85 \mathrm{MPa}$ and cooling time of 11 seconds gave minimum shrinkage. Cooling time was found to be most effective factor followed by refilling pressure. Injection pressure was found to be the least effective factor. It is hoped that this study will assist polymer engineers and researchers to produce high quality and defect free plastic products which will ultimately lead to high productivity in the plastic industries.

\section{REFERENCES}

Alireza, A; Mohammad, S (2011). Parameter Study in Plastic Injection Molding Process using 
Statistical Methods and IWO Algorithm. Inter. J. Model. Optimization. 1. 2.

Altan, M (2010). Reducing Shrinkage in Injection Moldings through the Taguchi, ANOVA and Neural Network Methods. J. Mat. Design, 31. 599-604.

Brydson, JA (1995). Plastic materials. ButterworthHeinmann: Oxford Publishers.

Gang XU1, Fangbao, D, Yihong, XU (2011). Adaptive Particle Swarm Optimization-Based Neural Network in Quality Prediction for Plastic Injection Moulding. J. Compute. Info. Syst.7 (2) 462-470.

Huang, MC; Tai, CC (2001). The effective factors in the warpage problem of an injection-moulded part with a thin shell feature. J. Mat. Proc. Tech., vol. 110, pp. 1-9, 2001.

James A; Aaronn B (2014). Cycle Time Reduction for Optimization of Injection Moulding Machine parameters for Process Improvements in Session 105-039.

Kothari, CR (2016). Research Methodology. New Age Publication.

Mohd, MA; Deepak, K (2013). Reducing Shrinkage in Plastic Injection Moulding using Taguchi Method in Tata Magic Head Light. Inter. J. Sci. Res. 2319-7064.
Neeraj, SC; Shahzad, A (2015). Optimization of Cycle Time of DVD-R Injection Moulding Machine. Inter. J. Engineer. Technol. (IJEST). Vol. 2, pp 201-210.

Osarenmwinda, JO; Olodu, DD (2015). Effect of Barrel Temperature on the Mechanical Properties of Injection Moulded Products. Nigeria Journal of Technology (NIJOTECH), vol. 34, No. 2, pp 292-296.

Pötsch, G; Michaeli, W (1995). Injection moulding: An introduction. Munich: Hanser Publishers, pp15-65.

Rosato, DV; Rosato, MG (2000). Injection moulding handbook. Massachusetts: Kluwer Academic Publishers.

Taguchi, G (1990). Introduction to quality engineering. New York; Mc Graw Hill.

Vaatainen, O; Pentti, J (2016). Effect of Processing Parameters on the Quality of Injection Moulded Parts by Using the Taguchi Parameter Design Method. J. Plastic Rubber Composite. 1, 21-217. 